\title{
PENGARUH GAYA MENGAJAR GURU TERHADAP MOTIVASI \\ DANHASILBELAJAR BIOLOGI PADA KONSEP SISTEM \\ PEREDARANDARAHMANUSIA SISWA KELAS VIII SMP HANG TUAH \\ LANTAMAL IX AMBON
}

\author{
Aknes Gerce Bulohroy ${ }^{1}$, J.F. Rehena ${ }^{2}$, S.I.A. Salmanu ${ }^{2}$ \\ ${ }^{1}$ Alumni Program Studi Pendidikan Biologi \\ ${ }^{2}$ Dosen Program Studi Pendidikan Biologi \\ E-mail : johanisrehena@yahoo.com
}

\begin{abstract}
Background: Education and teaching focusing on the interaction between educators with educated or teachers with students. The interaction of teachers and teaching in improving student learning outcomes especially on biological materials, desperately needs attention, motivation, and interest. It almost entirely uses a good teaching style.

Methods: This study was conducted for 1 month starting from $05^{\text {th }}$ of November until $05^{\text {th }}$ of December 2016. The purpose of this study is to influence of teacher's teaching style (Variable $X$ ) and motivation of student learning outcomes in Biology at SMP Hang Tuah Lantamal IX Ambon by taking sample of 35 respondents, are the students of class VIII.

Results: The results showed that there is a significant influence or perfect correlation between teacher teaching styles on the motivation of learning results of human's blood circulation system in grade VIII of SMP Hang Tuah Lantamal IX Ambon. It is proven by the product moment correlation value of pearson $r_{\text {arithematic }}=1.00$ when compared with $r_{\text {table }}=0.334$ and according to table interpretation of Pearson correlation coefficient.

Conclusion: Thus the hypothesis $\mathrm{H} 1$ which states there is a significant influence between teacher teaching styles on student learning outcomes motivation.
\end{abstract}

Keywords : Influence of teaching style, motivation, Student's Learning Outcomes

\begin{abstract}
Abstrak
Latar Belakang: Pendidikan dan pengajaran terfokus pada interaksi antara pendidik dengan terdidik atau guru dengan siswa.Interaksi pendidik dan pengajaran dalam meningkatkan hasil belajar siswa terutama pada materi biologi, sangat membutuhkan perhatian, motivasi dan minat. Hal ini hampir seluruhnya menggunakan gaya mengajar yang baik.

Metode: Penelitian ini dilaksanakan selama 1 bulan yang dimulai pada tanggal 05 November sampai dengan tanggal 05 Desember 2016. Tujuan penelitian ini untuk mengetahui pengaruh gaya mengajar guru ( variabel $X$ ) dan motivasi hasil belajar siswa dalam pembelajaraan IPA biologi di SMP Hang Tuah Lantamal IX Ambon dengan pengambilan sampel yang berjumlah 35 responden, yaitu siswa Kelas VIII.

Hasil: Hasil penelitian menunjukan bahwa terdapat pengaruh yang signifikan atau berkorelasi sempurna antara gaya mengajar guru terhadap motivasi hasil belajar materi sistem peredaran dara pada manusia kelas VIII SMP Hang Tuah Ambon. Hal ini terbukti nilai korelasi product moment dari pearson $r_{\text {hitung }}=1,00$ jika dibandingkan dengan nilai $r_{\text {table }}=0,334$ dan sesuai tabel interprestasi koefisien korelasi pearson.

Kesimpulan: Dengan demikian hipotesis $\mathrm{H}_{1}$ yang menyatakan ada pengaruh yang signifikan antara gaya mengajar guru terhadap motivasi hasil belajar siswa.
\end{abstract}

Kata Kunci: Pengaruh Gaya mengajar, Motivasi Hasil belajar Siswa 


\section{PENDAHULUAN}

Pendidikan adalah suatu organisasi yang menyediakan layanan di bidang pembentukan kepribadian manusia, sehingga pendidikan perlu direncanakan sebaik-baiknya sesuai dengan kebutuhan pada pelanggan, yaitu peserta didik dan orang tua serta masyarakat.Dinyatakan bahwa, terlaksanakannya secara baik bergantung pada kemampuan, kreaktifitas pemecahan masalah, desentralisasi pembuatan keputusan yang terbaik bagi peserta didik.Guru, orang tua, dan pengelola sekolah diberi kesempatan yang cukup luas untuk menentukan bahan ajar bagi peserta didik.Peran guru, orang tua, dan sekolah cukup besar dalam memberdayakan lingkungan sekolah yang bersahabat. Sehingga proses belajar mengajar berlangsung dengan baik (Euis, 2012).

Belajar mengajar adalah suatu kegiatan yang bernilai edukatif.Nilai edukatif mewarnai interaksi yang terjadi antara guru dengan anak didik atau siswa.Interaksi yang bernilai edukatif dikarenakan kegiatan mengajar yang dilakukan, diarahkan untukl mencapai tujuan tertentu yang telah dirumuskan sebelum pengajaran dilakukan. Guru dengan sadar merencanakan kegiatan pengajarannya secara sistematis dengan memanfaatkan segala sesuatu guna kepentingan pengajaran (Djamarah, 2002). Guru merupakan tonggak dan pendorong dalam semua proses pengajaran, baik pengajaran di dalam maupun di luar sekolah. Kedua peranan tersebut sangat penting dalam membantu pelajar meningkatkan keinginan di bidang akademik. Guru harus menggunakan kemampuannya untuk menarik minat pelajar, bukan hanya melakukan proses pembelajaran saja di sekolah, justru guru harus mampu membantu para siswa agar dapat terus maju dalam bidang akademik. Oleh karena itu guru disarankan melakukan perubahan dalam gaya pengajaran mereka di dalam sekolah untuk dapat disesuaikan dengan gaya pembelajaran yang membuat siswa dapat memahami materi yang diberikan kepada mereka. Gaya mengajar guru merupakan cara atau teknik seorang guru dalam menyampaikan isi pengajaran mereka. Gaya mengajar guru berkaitan dengan penyampaian, interaksi dan ciri-ciri kepribadian guru.

Berdasarkan hasil pengamatan sebelumnya secara umum peneliti peroleh informasi bahwa, hasil belajar siswa khususnya konsep biologi masih kurang. Salah satu penyebab dari hal tersebut terkait dengan kurangnya minat siswa untuk belajar Biologi. Hal tersebut sudah jelas tergambar dari kurangya relasi antara guru dan siswa dalam proses belajar mengajar, sehingga muncul kejenuhan dalam diri siswa. Degan demikian, hasil belajar yang diperoleh sebagian siswa masih di bawah KKM.Akibatnya situasi pembelajaran tersebut menyebabkan siswa pasif karena kurang motivasi untuk terlibat langsung dalam proses belajar mengajar, sehingga siswa tidak secara langsung berpengharuh terhadap tingkat pemahaman dan hasil belajar siswa yang sebagian besar tidak mencapai $\mathrm{KKM}$ yang terdapat disekolah yaitu $60 \%$.

\section{MATERI DAN METODE}

Jenis penelitian ini yaitu peneliatian Deskriptif. Penelitian ini dilaksanakan untuk memberikan informasi hasil belajar siswa kelas VIII SMP Hang Tuah Lantamal IX Ambon pada materi sistem peredaran darah pada manusia. Penelitian ini dilaksanakan di SMP Hang Tuah Lantamal IX Ambonu, dilaksanakan selama satu bulan sejak tanggal 05November sampai tanggal 05Desember 2016. Pada siswa kelas VIII SMP Hang Tuah Lantamal IX Ambon terdiri dari 2kelas yang berjumlah 72 Siswa.

Teknik pengumpulan data dalam penelitian ini adalah dengan menggunakan angket, kepustakaan, wawancara dan observasi. Dengan analisa data Uji validitas dan reliabilitas. Dimana uji validitas menunjukan tingkat kevalidan atau kesahihan suatu instrument. Sedangkan uji reliabilitas menunjukan suatu instrumen cukup dapat dipercaya untuk digunakan sebagai alat pengumpulan data kerena instrumen tersebut sudah baik.

\section{HASIL DAN PEMBAHASAN Hasil}

Guru pendidikan MIPA SMP Hang Tuah Lantamal IX Ambon sebagai 
pelaksanaan kurikulum pendidikan nasional berperan penting dalam peningkatan hasil belajar siswa terutama pada pendidikan MIPA mencakup aspek kognitif, efektif dan psikomotorik.
Berdasarkan hasil peninjauan di lokasi penelitian, terdapat guru MIPA SMP Hang Tuah Lantamal IX Ambon berjumlah 4 orang dengan perincian data sebagai berikut.

Tabel 1. Kualifikasi Guru MIPA SMP Hang Tuah Lantamal IX Ambon

\begin{tabular}{ccccc}
\hline No & Inisial & $\begin{array}{c}\text { Pendidikan } \\
\text { Terakhir }\end{array}$ & Mengajar & Status \\
\hline 1 & Ny. A & S1 & Biologi & Guru tetap \\
2 & Ny. B & S1 & Fisika & Guru tetap \\
3 & Ny. C & S1 & Matematika & Guru tetap \\
\hline
\end{tabular}

SMP Hang Tuah Lantamal IX Ambon dalam pembelajran di kelas VIII hanya memiliki 1 guru Biologi yaitu lbu J. Wajabula, S.Pd yang memiliki masa mengajar selama 16 tahun metode yang digunakan dalam mengajar yaiu metode ceramah dengan menggunakan power point serta papan tulis sebagai media pembelajaran. Pemberian tugas yang diberikan kepada siswa berupa LKS saat pembelajaraan maupun diuar kelas.

\section{Penilaian Gaya Mengajar Guru}

Untuk menunjukan deskriptif tentang karakteristik skor dari masing-masing variabel penelitian dan sekaligus menjawab masalah yang telah dirumuskan dalam penelitian ini, maka bagian ini di perlihatkan hasil deskriptif dari setiap variabel.

Berdasarkan hasil analisis pada tabel rekapitulasi skor penilain mengajar guru kelas VIII SMP Hang Tuah Lantamal IX Ambon pada lampiran, sedangkan nilai rata-rata penilain mengajar guru dapat dilihat pada tabel 2.

Tabel 2. Nilai Rata-rata Penilaian Gaya Mengajar guru

\begin{tabular}{|c|c|c|c|c|}
\hline \multirow{2}{*}{ Variable X } & \multicolumn{2}{|c|}{ Skor Perolehan Pengamat } & \multirow{2}{*}{$\begin{array}{c}\text { Rata-rata } \\
(\%)\end{array}$} & \multirow{2}{*}{ Kualifikasi } \\
\hline & $I(\%)$ & II (\%) & & \\
\hline 1 & 95.7 & 91.3 & 93.5 & Baik \\
\hline 2 & 90.5 & 81 & 92 & Baik \\
\hline 3 & 93.5 & 96.5 & 85.5 & Baik \\
\hline 4 & 93,5 & 100 & 96.5 & Baik \\
\hline 5 & 81 & 84.5 & 82.5 & Baik \\
\hline 6 & 87.4 & 89,8 & 88.6 & Baik \\
\hline 7 & 74.3 & 87 & 80.5 & Baik \\
\hline 8 & 89.8 & 87.2 & 88.5 & Baik \\
\hline
\end{tabular}

Keterangan: 1. Penilaian membuka pelajaran. 2. Penilaian menjelaskan. 3. Penilaian membuat penguatan. 4. Penilaian mengadakan variasi. 5. Penilaian mengelola kelas. 6. Penilaian memimpin kelompok kecil. 7. Penilaian bertanya. 8. Penilaian menutup pelajaran.

Berdasarkan data tabel 2 di atas maka menunjukan bahwa kualifikasi penilaian mengajar guru kelas VIII SMP Hang Tuah Lantamal IX Ambon tergolong baik, yaitu; variabel $X_{1}$ nilai rata-rata $93.5 \%, X_{2}$ nilai rata-rata $92 \%, X_{3}$ nilai rata-rata $85.5 \%$.

\section{Hasil belajar}

Hasil analisis deskriptif nilai hasil belajar pada materi sistem peredaran darah pada manusia dapat dilihat pada lampiran 8 halaman 75 dan secara sederhana disajikan dalam tabel 3 dapat digolongkan ke dalam kualifikasi; sangat baik, baik, cukup, dan gagal sebagai berikut. 


\begin{tabular}{cccc}
\hline Interval Nilai & Frekuansi & Presentase (\%) & Kualifikasi \\
\hline $85-100$ & 8 & 22.4 & Sangat Baik \\
$70-84$ & 21 & 60 & Baik \\
$56-69$ & 4 & 11.7 & Cukup \\
$<55$ & 2 & 5.9 & Gagal \\
Jumlah & 35 & $100 \%$ & \\
\hline
\end{tabular}

Berdasarkan data tabel 3 di atas, menunjukan bahwa jumlah siswa yang berkualifikasi sangat baik sebanyak 8 orang (22.4\%), baik sebanyak 21 orang $(60 \%)$, cukup sebanyak 4 orang $(11.7 \%)$, dan gagal sebanyak 2 orang (5.9\%).

Nilai rata-rata hasil belajar siswa kelas VIII SMP Hang Tuah Ambon pada materi sistem peredaran darah pada manusia dalah 74 berkualifikasi baik (lihat lampiran 8 halaman 75), dengan demikian dapat dikatakan bahwa penerapan gaya mengajar guru yang dimiliki guru kelas VIII telah dapat memberikan siswa menyerap atau menguasai konsep sistem peredaran darah pada manusia dengan baik.

\section{Penilaian Siswa Selama Proses Belajar Mengajar}

Penilaian selama proses belajar mengajar dilakukan dengan berpatokan pada 3 aspek yaitu aspek kognitif, aspek afektif dan aspek psikomotor. Penilaian terhadap aspek kognitif melalui lembar kerja siswa (LKS) sedangkan aspek afektif dan psikomotor dilakukan penilaian langsung selama proses belajar mengajar.

\section{Hasil Penilaian Aspek Kognitif}

Hasil pencapaian aspek kognitif yang dinilai selama proses pembelajaran melalui LKS. Kualifikasi pencapaian siswa dapat dilihat pada tabel 4 .

Tabel 4. Kualifikasi Pencapaian Hasil Belajar Pada Aspek Kognitif

\begin{tabular}{cccc}
\hline Interval Nilai & Frekuansi & Presentase (\%) & Kualifikasi \\
\hline $85-100$ & 35 & $100 \%$ & Sangat Baik \\
$70-84$ & - & - & Baik \\
$56-69$ & - & - & Cukup \\
$<55$ & - & - & Gagal \\
Jumlah & 35 & $100 \%$ & \\
\hline
\end{tabular}

Berdasarkan tabel 4 untuk hasil penilaian menunjukan terdapat 35 siswa $(100 \%)$ memperoleh nilai pada interval (85100) dengan klasifikasi sangat baik.

\section{Hasil Penilaian Aspek Afektif}

Penilaian afektif diperoleh melalui lembar observasi yang digunakan untuk melalui kemampuan siswa yang meliputi 6 aspek yaitu bekerja sama, berinisyatif, penuh perhatian, bekerja sistematis, cermat dan kritis.

Tabel 5 kualifikasi Pencapaian Hasil Belajar Pada Aspek Afektif

\begin{tabular}{cccc}
\hline Interval Nilai & Frekuansi & Presentase (\%) & Kualifikasi \\
\hline $85-100$ & 5 & $14,29 \%$ & Sangat Baik \\
$70-84$ & 30 & $85,71 \%$ & Baik \\
$56-69$ & - & - & Cukup \\
$<55$ & - & - & Gagal \\
Jumlah & 35 & $100 \%$ & \\
\hline
\end{tabular}

Berdasarkan tabel 5 di atas menunjukan terdapat 5 siswa $(14,29 \%)$ memperoleh nilai interval (85-100) dengan kualifikasi sangat baik dan 30 siswa $(85,71 \%)$ memperoleh nilai interval baik. 
Biopendix, Volume 4, Nomor 1, Oktober 2017, hlm. 56-62

Hasil Penilaian Aspek Psikomotor

Berdasarkan data hasil penilaian pada aspek psikomotor dengan menggunakan penilaian proses belajar yang dilakukan berdasarkan 5 indikator. Hasil ini kemudian di konvensi dalam tabel 6.

Tabel 6. Kualifikasi Pencapaian Hasil Belajar Pada Aspek Psikomotor

\begin{tabular}{cccc}
\hline Interval Nilai & Frekuansi & Presentase (\%) & Kualifikasi \\
\hline $85-100$ & 7 & $20 \%$ & Sangat Baik \\
$70-84$ & 28 & $80 \%$ & Baik \\
$56-69$ & - & - & Cukup \\
$<55$ & - & - & Gagal \\
Jumlah & 35 & $100 \%$ & \\
\hline
\end{tabular}

Dari tabel diatas, terlihat bahwa terdapat 7 siswa (20\%) yang memiliki nilai interval antara (85-100) dengan memperoleh nilai klasifikasi sangat baik, sedangkan 28 siswa (80\%) memiliki nilai interval (70-84) dengan memperoleh nilai klasifikasi baik.

\section{Pembahasan}

Deskripsi jawaban dari responden yang paling dominan adalah nilai 3 (setuju), dengan presentase $60 \%$, untuk jawaban dengan nilai 4 (sangat setuju), dengan presentase $34,28 \%$, untuk jawaban dengan nilai 2 (ragu-ragu), dengan presentase $5,72 \%$, untuk jawaban dengan nilai 1 (tidak setuju), dengan presentase 0 . Tertinggi dari jawaban responden adalah sebesar $60 \%$ (setuju) dan terendah adalah 5,72\% (raguragu). Sebanyak 21 siswa setuju dengan gaya mengajar guru, sebanyak 12 siswa sangat setuju dengan gaya mengajar guru, dan sebanyak 2 siswa ragu-ragu dengan gaya mengajar guru.

Dengan bantuan SPSS for Windows Versi 16,0 diperoleh validitas untuk gaya menagajar guru semuanya dinyatakan valid karena nilai $r$ hitung lebih besar dari nilai $r$ tabel (0.021). dan untuk uji reabilitas, diperoleh reabilitas variabel gaya mengajar memiliki nilai cronbach alpha 0,922. Dengan demikian nilai alpha dalam penelitian ini $>0,6$. Maka dapat disimpulkan bahwa instrument untuk masing-masing variabel dinyatakan reliabel untuk digunakan dalam penelitian.

Uji hipotesis ini menggunakan teknik analisis korelasi dengan menggunakan bantuan program SPSS for Windows versi 16,0 , menunjukan bahwa nilai signifikan untuk hubungan motivasi dengan gaya mengajar guru sebesar 0,000 artinya karna nilainya lebih kecil dari 0,05 maka dapat dikatakan bahwa terdapat korelasi. Untuk koefisien korelasi $\mathrm{X}$ terhadap $\mathrm{Y}$ sebesar 1,00 . Karena koefisien korelasi tersebut bernilai positif maka dapat diketahui bahwa terdapat pengaruh positif antara Gaya Mengajar Guru dengan Motivasi Hasil Belajar Siswa SMP Hang Tuah Lantamal IX Ambon. Sesuai dengan data sampel $(\mathrm{N}=35)$, bila persepsi siswa terhadap Gaya Mengajar Guru semakin baik maka akan meningkatkan Motivasi Hasil Belajar Biologi dan sebaliknya.

Penilaian penerapan gaya mengajar guru biologi pada SMP Hang Tuah Lantamal IX Ambon dapat dikatakan sudah baik, hal ini sesuai dengan taraf kualifikasi penilaian gaya mengajar guru yang diperoleh guru pada kelas VIII. Berdasarkan hasil tes harian dalam penilaian gaya mengajar guru untuk materi sistem peredaran darah pada manusia diperoleh hasil belajar siswa di kelas VIII nalai ratarata 74 dengan taraf kualifikasi baik.

Kemampuan kognitif siswa yang dinilai sesuai Lembar Kerja Siswa (LKS) dan tes formatif selama proses pembelajaran berada pada kualifikasi tuntas. Berdasarkan presentase pencapaian aspek kognitif, maka kelas yang diajarkan menerapkan gaya mengajar yang dapat membangkitkan motivasi belajar siswa (100\%) atau 35 siswa berada pada kualifikasi tuntas.

Penilain dalam aspek afektif dinilai berdasarkan kriteria penilaian (Ratumanan, 2004) pada pertemuan yang dilakukan terhadap kelas yang menjadi aspek penilaian adalah bekerja sama, berinisyatif, penuh perhatian, bekerja sistematis, cermat dan kritis selama kegiatan pembelajran berlangsung dalam kelas yang digambarkan pada tabel 4.6 yang 
menunjukan bahwa sebanyak (100\%) atau 35 siswa masuk dalam kualifikasi tuntas.

$$
\text { Hasil belajar psikomotor dapat }
$$

dilakukan dengan observasi atau pengamatan. Observasi sebagai alat banyak digunakan untuk mengukur tingkah laku individu ataupun proses terjadinya suatu kegiatan yang dapat diamati.Penilaian psikomotor yang dinilai berdasarkan kriteria penilaian bahasa tubuh seperti kontak mata, postur dan gerakan tubuh digunkan secara aktif, mendengarkan dengan aktif apa yang disampaikan oleh teman, mendengar atau menerima dengan aktif penjelasan dari guru, bertanya dengan menggunakan bahasa yang baik dan benar, menuliskan apa yang disampaikan oleh guru.

Nilai akhir siswa disajikan dalam bentuk deskriptif yang diperoleh dengan penilaian proses (6P) dan nilai tes formatif (4F). pembelajaran dikatakan berhasil dan berkualitas apabila seluruhnya atau setidaktidaknya sebagian besar peserta didik terlibat secara aktif, baik fisik, mental maupun social dalam proses pembelajran. Pencapaian kompetensis siswa yang meliputi aspek kognitif siswa dari hasil penilain proses kognitif dalam mengerjakan LKS, aspek afektif dan aspek psikomotor dalam lembar penilaian serta hasil tes formatif dapat dilihat dari perolehan nilai akhir yang memuat tentang hasil pencapaian nilai akhir siswa yang didapat dari penggabungan nilai nilai yang diperoleh siswa, maka pencapaian nilai akhir pada kelas VIII terlihat bahwa seluruh siswa mencapai ketuntasan belajar meskipun dengan klasifikasi yang berbeda-beda. Hal ini sesuai dengan Slavin (1995), pembelajaran kooperatif berpengaruh terhadap kemampuan akademik siswa dimana siswa lebih memiliki kemungkinan tingkat berpikir yang lebih tinggi selama dan setelah diskusi dalam kelompok.

Berdasarkan analisis data diketahui bahwa secara simultan variabel bebas gaya mengajar guru dan motivasi belajar siswa mempunyai pengaruh yang signifikan terhadap hasil belajar. Hal ini diperkuat dengan hasil penelitian Efrida yang menunjukkan bahwa agar kegiatan belajar mengajar ini diterima oleh para siswa, guru perlu berusaha membangkitkan gairah minat belajar mereka. Kebangkitan gairah dan minat belajar para siswa akan mempermudah guru dalam menghubungkan kegiatan mengajar dengan kegiatan belajar. Salah satu bentuk gairah itu tercermin dari motivasi belajar.

Dalam hal ini motivasi memegang peran yang dominan. Karena itu pembahasan gairah dan minat dalam motivasi belajar tidak bisa dilepaskan dari gaya atau cara mengajar guru ketika menyampaiakan materi pelajaran. Semakin tepat gaya atau cara mengajar guru maka peluang memperoleh hasil pembelajaran para siswa yang sesuai dengan harapan pun akan lebih besar. Dan hasil belajar yang baik pun akan mudah dicapai oleh siswa. Oleh karena itu gaya mengajar guru dan motivasi belajar siswa adalah salah satu faktor yang dapat mempengaruhi hasil belajar siswa.

Pengujian secara parsial untuk variabel gaya mengajar guru menunjukkan bahwa variabel gaya mengajar guru mempunyai pengaruh yang signifikan terhadap variabel motivasi hasil belajar. Hal ini diperkuat dengan pernyataan Suparman (2010:88) yang menyatakan bahwa bagi anak didik atau siswa, adanya gaya mengajar guru dilihat sebagai suatu yang positif, energik, bersemangat, menyenangkan, dan semuanya memiliki hubungan yang erat terhadap pencapaian hasil belajar yang maksimal. Gaya mengajar yang dilakukan oleh guru akan membuat suasana belajar yang dinamis, hidup, dan meningkatkan komunikasi yang baik antara guru dengan siswa. disamping itu gaya mengajar juga bisa menjadi stimulus yang positif terhadap proses penerimaan pelajaran yang sedang berlangsung. Sehingga dapat disimpulkan adanya gaya mengajar guru mampu meningkatkan hasil belajar siswa. Sedangkan untuk variabel motivasi belajar siswa menunjukkan bahwa variabel motivasi belajar siswa memiliki pengaruh yang signifikan terhadap hasil belajar.hal ini diperkuat dengan pendapat Sardiman (2007:85) yang mengungkapkan bahwa motivasi dapat berfungsi sebagai pendorong usaha dan pencapaian prestasi. Seorang melakukan suatu usaha karena adanya motivasi. Adanya motivasi yang baik dalam belajar akan menunjukkan hasil yang baik. Dengan kata lain, dengan adanya usaha yang tekun dan terutama 
didasari adanya motivasi, maka seseorang yang belajar itu akan dapat melahirkan prestasi yang baik. Sehingga intensitas motivasi seorang siswa akan sangat menentukan tingkat pencapaian prestasi belajar seseorang.

Berdasarkan hasil penelitian yang diperoleh bahwa korelasi antara gaya mengajar guru dan motivasi hasil belajar siswa pada kelas VIII terdapat korelasi yang sempurna. Untuk kelas VIII diperoleh nilai $r_{p m}=1,00$. Artinya semakin baik guru dalam menerapkan gaya mengajar maka akan semakin baik pula hasil belajar siswa. Nilai $r_{\text {hitung }} 1,00$ tersebut di atas jika dibandingkan dengan $r_{\text {table }}$ pada taraf 0,05 dan $\mathrm{N}=35$, maka $r_{\text {table }}=0,334$. Dengan demikian $r_{\text {hitung }}>$ $r_{\text {table }}$ sehingga ada pengaruh antara gaya mengajar guru dengan motivasi hasil belajar siswa berkorelasi sempurna sesuai tabel interprestasi koefisien korelasi person.

\section{KESIMPULAN}

Berdasarkan hasil penelitian dan pembahasan, maka dapat ditarik kesimpulan bahwa terdapat pengaruh yang signifikan atau berkorelasi sempurna antara gaya mengajar guru terhadap motivasi hasil belajar materi sistem peredaran dara pada manusia kelas VIII SMP Hang Tuah Ambon. Hal ini terbukti nilai korelasi product moment dari pearson $r_{\text {hitung }}=1,00$ jika dibandingkan dengan nilai $r_{\text {table }}=0,334$ dan sesuai tabel interprestasi koefisien korelasi pearson. Dengan demikian hipotesis $\mathrm{H}_{1}$ yang menyatakan ada pengaruh yang signifikan antara gaya mengajar guru terhadap motivasi hasil belajar siswa.

\section{DAFTAR PUSTAKA}

Djamarah, Syaiful, 2002. Psikologi Belajar. Jakarta PT Rineka Ciptas.

Euis Fatimah, 2012. Pengaruh Penggunaan Media. Universitas Pendidikan Indonesia.

Sardiman, (2007).Interaksi dan Motivasi BelajarMengajar. Jakarta: PT. Gravindo Persada.

Suparman, S., (2010) Gaya Mengajar yang Menyenangkan Siswa, Yogyakarta: Pinus Book'Publisher.

Sumandi Suryabrata. 1989:11. Psikologi Pendidikan. Yogyagkarta: Andi Offset.

Slameto. 2003. Belajar dan Faktor-Faktor yang Mempengaruhinya. Jakarta Rineks Cipta Ahmadi. 